\title{
Epilepsiliknende anfall som ikke er epilepsi
}

Pasienter med psykogene ikke-epileptiske anfall beveger seg i grenseland mellom nevrologi og psykiatri. Ifølge dagens praksis stilles diagnosen av nevrolog, som deretter overlater behandlingen av pasienten til psykolog eller psykiater. I denne prosessen er det flere potensielle vansker. Mange pasienter opplever anfallene som fysiske, de føler seg ikke psykisk syke, og kan ha problemer med å forstå og godta diagnosen (1). Videre kan det ta lang tid mellom diagnose og tilbud om behandling. Mange pasienter uten åpenbare psykiatriske problemer får ikke tilbud om behandling i det hele tatt, fordi de ikke blir oppfattet som syke nok. Det kan også være mangelfulle kunnskaper om tilstanden i det psykiatriske behandlingsapparatet.

Pasientgruppen er heterogen, og det kan være utfordrende å skreddersy behandlingen til den enkelte. De som ikke har gjennomgått større traumer eller har alvorlig psykiatrisk sykdom, kan bli anfallsfrie etter å ha fått formidlet diagnosen på en empatisk måte (2). De fleste vil imidlertid ha behov for behandling. Mannen i denne kasuistikken ble grundig utredet, og han mottok behandling fra flere ulike instanser. Likevel ble han ikke bedre av sine anfall før han fikk diagnostisert og behandlet en bipolar lidelse. Komorbide psykiatriske tilstander er svært vanlige i denne pasientgruppen, særlig i form av depresjon, angst og personlighetsforstyrrelser. I en nylig publisert studie hadde $10 \%$ av pasientene en bipolar lidelse (3). I behandling av pasienter med psykogene ikke-epileptiske anfall er det viktig å identifisere og be- handle slike komorbide lidelser. Ubehandlet depresjon og angst er assosiert med vedvarende anfall (4).

Man tror i dag at både psykologiske faktorer og biologisk sårbarhet spiller en rolle for utviklingen av tilstanden (2). Hos rundt $20 \%$ av pasientene er det patologiske funn ved cerebral MR, EEG eller nevropsykologisk testing (5). De senere årene er det identifisert flere nevrobiologiske markører hos pasientene, og man er i ferd med å utarbeide en biopsykososial forståelse av tilstanden (2).

Etiologien er kompleks og kan bestå av ulike faktorer, som tidligere gjennomgåtte traumer, vanskelige livshendelser, dysfunksjonelle familieforhold, psykiatrisk komorbiditet og hjerneorganisk dysfunksjon. Manglende helhetlig pasientforløp medfører ofte at diagnosen i seg selv blir en tilleggsbelastning for pasienten (1). Vi finner det ikke vanskelig å slutte oss til forfatterne når de etterlyser et tettere samarbeid mellom nevrologer og psykiatere generelt, og rundt denne pasientgruppen spesielt.

\section{Caroline Lund}

caroline.lund@ous-hf.no Hilde Nordahl Karterud

Caroline Lund (f. 1971) er under utdanning i nevrologi og har i flere år arbeidet ved Avdeling for kompleks epilepsi - SSE ved Oslo universitetssykehus. Hun er nå stipendiat ved Oslo universitetssykehus/Universitetet i Oslo. Forfatter har fylt ut ICMJE-skjemaet og har ingen oppgitte interessekonflikter.
Hilde Nordahl Karterud (f.1956) er ph.d.-stipendiat ved Universitetet i Oslo. Hun er psykiatrisk sykepleier og leder av Lærings-og mestringssenteret ved Avdeling for kompleks epilepsiSSE, Oslo universitetssykehus. Forfatter har fylt ut ICMJE-skjemaet og har ingen oppgitte interessekonflikter.

\section{Litteratur}

1. Karterud HN, Knizek BL, Nakken KO. Changing the diagnosis from epilepsy to PNES: patients' experiences and understanding of their new diagnosis. Seizure 2010; 19: 40-6.

2. Reuber M, Mayor R. Recent progress in the understanding and treatment of nonepileptic seizures. Curr Opin Psychiatry 2012; 25: 244-50.

3. Driver-Dunckley E, Stonnington CM, Locke DEC et al. Comparison of psychogenic movement disorders and psychogenic nonepileptic seizures: is phenotype clinically important? Psychosomatics 2011; 52: 337-45.

4. Kanner AM. Is the neurologist's role over once the diagnosis of psychogenic nonepileptic seizures is made? No! Epilepsy Behav 2008; 12: 1-2.

5. Reuber M, Fernández G, Helmstaedter $C$ et al. Evidence of brain abnormality in patients with psychogenic nonepileptic seizures. Epilepsy Behav 2002; 3: 249-54.

Mottatt 4.1. 2013 og godkjent 27.1. 2013. Medisinsk redaktør Are Brean.

Engelsk oversettelse på www.tidsskriftet.no 